\title{
UPAYA MENINGKATKAN HASIL BELAJAR PJOK MATERI LARI SPRINT MELALUI PERMAINAN HITAM-HIJAU PADA SISIWA KELAS V SD NEGERI 1 JERO GUNUNG
}

\author{
AZHAR \\ SD Negeri 1 Jero Gunung \\ e-mail: ujon80@gmail.com
}

\begin{abstract}
ABSTRAK
Jenis penelitian yang dilakukan adalah Penelitian Tindakan Kelas (PTK). Tujuan dari Penelitian Tindakan Kelas (PTK) ini adalah untuk meningkatkan hasil belajar PJOK materi lari sprint melalui permainan hitam hijau pada kelas V SD Negeri 1 Jero Gunung Kecamatan Sakra Barat Kabupaten Lombok Timur Tahun pelajaran 2021/2022. Dalam Penelitian Tindakan Kelas (PTK) ini dilakukan dalam 2 siklus, dari hasil tindakan yang dilakukan terbukti dapat meningkatkan kinerja guru dengan mencapai ketuntasan klasikal yang ditetapkan yaitu $85 \%$. Ketuntasan Klasikal 70\% diperoleh pada siklus I, dapat meningkat pada siklus II menjadi 100 $\%$. Dari segi aktivitas belajar siswa juga ada peningkatan yaitu pada siklus I diperoleh kategori cukup aktif meningkat menjadi kategori aktif. Hasil penelitian tindakan ini menunjukkan bahwa penerapan permainan hitam hijau pada materi pembelajaran lari sprint dapat meningkatkan hasil belajar siswa pada siswa kelas V SD negeri 1 Jero Gunung Kecamatan Sakra Barat Kabupaten Lombok Timur ketuntasan mencapai $100 \%$.
\end{abstract}

Kata Kunci: Hasil belajar, lari sprint, permainan hitam hijau

\section{ABSTRACT}

The type of research conducted is Classroom Action Research (CAR). The purpose of this Classroom Action Research (CAR) is to improve learning outcomes of PJOK sprint running material through black and green games in class V SD Negeri 1 Jero Gunung, West Sakra District, East Lombok Regency, for the 2021/2022 academic year. In this Classroom Action Research (CAR) was carried out in 2 cycles, from the results of the actions taken it was proven to be able to improve teacher performance by achieving the specified classical completeness of $85 \%$. Classical completeness $70 \%$ obtained in the first cycle, can be increased in the second cycle to $100 \%$. In terms of student learning activities, there was also an increase, namely in the first cycle, the quite active category increased to an active category. The results of this action research indicate that the application of black and green games in sprint running learning materials can improve student learning outcomes in fifth grade students of SD Negeri 1 Jero Gunung, West Sakra District, East Lombok Regency, achieving 100\% completeness.

Keywords: Learning outcomes, sprint running, black and green game

\section{PENDAHULUAN}

Menurut Ki Hajar Dewantara (Bapak Pendidikan Nasional) Pendidikan yaitu tuntutan di dalam hidup tumbuhnya anak-anak, adapun maksudnya, pendidikan yaitu menuntun segala kekuatan kodrat yang ada pada anak-anak itu, agar mereka sebagai manusia dan sebagai anggota masyarakat dapatlah mencapai keselamatan dan kebahagiaan setinggi-tingginya. Dengan kata lain Pendidikan adalah usaha sadar untuk menyiapkan peserta didik melalui kegiatan bimbingan, pengajaran, dan atau latihan bagi peranannya di masa yang akan datang.

Sedangankan menurut H. Home Pendidikan adalah proses yang terus menerus (abadi) dari penyesuaian yang lebih tinggi bagi makhluk manusia yang telah berkembang secara fisik dan mental, yang bebas dan sadar kepada vtuhan, seperti termanifestasi dalam alam sekitar intelektual, emosional dan kemanusiaan dari manusia.

Dari beberapa pengertian pendidikan menurut ahli tersebut maka dapat disimpulkan bahwa Pendidikan adalah Bimbingan atau pertolongan yang diberikan oleh orang dewasa 
kepada perkembangan anak untuk mencapai kedewasaannya dengan tujuan agar anak cukup cakap melaksanakan tugas hidupnya sendiri tidak dengan bantuan orang.

Menurut Undang-Undang Nomor 20 tahun 2003 tentang Sistem Pendidikan Nasional, Pasal 3, tujuan pendidikan nasional adalah mengembangkan potensi peserta didik agar menjadi manusia yang beriman dan bertakwa kepada Tuhan Yang Maha Esa, berakhlak mulia, sehat, berilmu, cakap, kreatif, mandiri, dan menjadi warga negara yang demokratis serta bertanggung jawab.

Menurut UUD 1945, Pengertian Pendidikan Sekolah Dasar merupakan suatu upaya untuk mencerdaskan dan mencentak kehidupan bangsa yang bertaqwa, cinta dan bangga terhadap bangsa dan negara, terampil, kreatif, berbudi pekerti, dan santun serta mampu menyelesaikan permasalahan dilingkungannya. Pendidikan sekolah dasar adalah pendidikan anak yang berusia 7 sampai 13 tahun sebagai pendidikan di tingkat dasar yang dikembangkan sesuai dengan satuan pendidikan, potensi daerah, dan sosial budaya.

Sedangkan dalam UUD No. 20 Tahun 2003 dijelaskan bahwa pendidikan adalah suatu usaha sadar dan terencana untuk mewujudkan suasana pembelajaran dan proses belajar agar peserta didik dapat secara aktif mengembangkan potensi dirinya untuk memiliki kekuatan spiritual keagamaan, kepribadian, pengendalian diri, kecerdasan, akhlak mulia, dan keterampilan yang diperlukan dirinya, masyarakat,bangsa, dan negara.

Pengertian Pendidikan sekolah dasar juga memiliki makna yang sama dengan penjelasan yang terurai diatas, akan tetapi ada perbedaan dengan audience nya, yaitu siswa kelas dasar 1 sampai 6 yang ketentuan materi dan pokok bahasannya diatur dalam GBPP (GarisGaris Besar Program Pengajaran)

Pendidikan jasmani Olahraga dan Kesehatan merupakan bagian integral dari pendidikan secara keseluruhan, bertujuan untuk mengembangkan aspek kebugaran jasmani, keterampilan gerak, ketrampilan berfikir kritis, keterampilan sosial, penalaran, stabilitas emosional, tindakan moral, aspek pola hidup sehat dan pengenalan lingkungan bersih melalui aktivitas jasmani, olahraga dan kesehatan terpilih yang direncanakan secara sistematis dalam rangka mencapai pendidikan nasional. Menurut Sukintaka (2000: 2) pendidikan jasmani olahraga dan kesehatan merupakan bagian integral dari pendidikan total yang mencoba mencapai tujuan mengembangkan kebugaran jasmani, mental, sosial, serta emosional bagi masyarakat dengan wahana aktivitas jasmani.

Menurut Wawan S. Suherman (2004: 23) Pendidikan jasmani olahraga dan kesehatan adalah suatu proses pembelajaran melalui aktivitas jasmani yang didesain untuk meningkatkan kebugaran jasmani, mengembangkan keterampilan motorik, pengetahuan dan perilaku hidup sehat dan aktif, dan sikap sportif, kecerdasan emosi. Lingkungan belajar diatur seksama untuk meningkatkan pertumbuhan dan perkembangan seluruh ranah, jasmani, psikomotor, kognitif, dan afektif setiap siswa.

Menurut uraian di atas dapat diambil kesimpulan bahwa Pendidikan Jasmani merupakan media untuk mendorong perkembangan keterampilan motorik kemampuan fisik, pengetahuan, penalaran, penghayatan nilai (sikap, mental, emosional, spiritual, sosial) dan pembiasaan pola hidup sehat yang bermuara untuk merangsang pertumbuhan serta perkembangan yang seimbang dalam rangka sistem pendidikan nasional. Dalam proses pembelajaran Pendidikan Jasmani guru diharapkan mengajarkan berbagai keterampilan gerak dasar, teknik dan strategi permainan dan olahraga, internalisasi nilai- nilai (sportifitas, jujur, kerjasama, dan lain-lain) serta pembiasaan pola hidup sehat. Dalam proses pembelajaran pendidikan jasmani guru harus dapat mengajarkan berbagai keterampilan gerak dasar, tehnik dan strategi media alat bantu/olahraga, internalisasi nilai-nilai (sportivitas, jujur kerjasama, dll). Aktifitas yang diberikan dalam pengajaran harus mendapatkan sentuhan didaktik-metodik, sehingga aktifitas yang dilakukan dapat mencapai tujuan pengajaran.

Pembelajaran lari sprint siswa kelas V SD Negeri 1 Jero Gunung Kecamatan Sakra Barat Kabupaten Lombok Timur banyak mengalami permasalahan yang timbul dalam pembelajaran dengan hasil pembelajaran siswa yang kurang dari nilai rata-rata di bawah nilai 
KKM 75 yang telah ditentukan guru. Beberapa faktor yang menyebabkan tidak tercapainya kriteria ketuntasan minimal (KKM) adalah adanya kondisi yang mengharuskan sekolah menerapkan sistem pembelajaran tatap muka terbatas akibat pandemi Covid-19 namun tetap menerapkan protokol kesehatan, pembelajaran yang monoton, kurangnya pengembangan pembelajaran, tingkat pemahaman siswa yang rendah, kurangnya minat siswa terhadap materi lari sprint, banyak siswa enggan melaksanakan kegiatan yang diberikan oleh guru karena kebanyakan siswa mempunyai pandangan bahwa lari adalah kegiatan melelahkan sehingga mengakibatkan siswa tidak tertarik dengan kegi atan lari.

Salah satu cara menumbuhkan atau meningkatkan keaktifan siswa dalam mengikuti pembelajaran pendidikan jasmani adalah dengan metode bermain, dalam penelitian tindakan kelas ini peneliti bermaksud ingin menerapkan permainan hitam hijau dalam pelaksanaan pembelajaran lari sprint dengan harapan dapat meningkatkan hasil belajar siswa.

Setelah peneliti mengamati hal-hal tersebut, peneliti mencoba menerapkan pembelajaran dengan metode pendekatan bermain, peneliti berupaya memasukan unsur permainan kedalam materi lari sprint dengan tujuan agar siswa merasa senang, tidak merasa jenuh dalam kegiatan pembelajaran serta menciptakan suasana kegembiraan dengan harapan materi lari sprint dapat disenangi oleh siswa sehingga tercapai tujuan pembelajaran.

Berdasar uraian diatas, maka peneliti bermaksud mengambil tema penelitian yang berkaitan dengan materi lari sprint, maka judul penelitian adalah " Upaya Meningkatkan Hasil Belajar Lari Sprint melalui Permainan Hitam-Hijau pada Siswa Kelas V SD Negeri 1 Jero Gunung Kecamatan Sakra Barat Kabupaten Lombok Timur Tahun Pelajaran 2021/2022 ”.

\section{METODE PENELITIAN}

Subyek penelitian adalah siswa kelas V SD Negeri 1 Jero Gunung kecamatan Sakra Barat Kabupaten Lombok Timur Tahun Pelajaran 2021/2022 yang berjumlah 33 siswa dan terdiri atas 15 siswa laki-laki dan 18 siswa perempuan dengan usia rata-rata 11 tahun, karena masa covid-19 sehingga subyek penelitian diambil 17 siswa. Subyek penelitian adalah siswa kelas V SD Negeri 1 Jero Gunung kecamatan Sakra Barat Kabupaten Lombok Timur Tahun Pelajaran 2021/2022 yang berjumlah 33 siswa dan terdiri atas 15 siswa laki-laki dan 18 siswa perempuan dengan usia rata-rata 11 tahun, karena masa covid-19 sehingga subyek penelitian diambil 17 siswa. Penelitian ini dilaksanakan dengan menggunakan dua siklus, dengan setiap siklusnya dilaksanakan 2 kali pertemuan. Penelitian ini dilaksanakan selama kurang lebih tiga bulan, yaitu mulai Bulan Agustus sampai dengan Oktober 2021.

Prosedur penelitian dibagai menjadi dua siklus, siklus I yaitu perencanaan tindakan, pelaksanaan tindakan, observasi dan evaluasi, dan refleksi, kemudian pada siklus II yaitu perencanaan dan pelaksanaan tahapan pada siklus II tidak berbeda dengan tahapan pada siklus I, hanya saja kekurangan pada siklus 1 diharapkan dapat diperbaiki pada siklus II. Teknik pengumpulan data yaitu instrumen pelaksanaan pembelajaran yang digunakan berupa silabus dan rencana pelaksanaan pembelajaran (RPP). Menurut Suharsimi Arikunto dalam buku Prosedur Penelitian Suatu Pendekatan Praktik diterbitkan di Jakarta oleh Rineka Cipta (2006:160) menerangkan bahwa instrumen penelitian adalah alat atau fasilitas yang digunakan oleh peneliti dalam mengumpulkan data agar pekerjaan lebih mudah dan hasilnya lebih baik, dalam arti lebih cermat, lengkap dan sistematis sehingga lebih mudah diolah.

Instrumen pengumpulan data yang dimulai dari dokumentasi yang berupa data-data siswa, observasi dengan pengamatan meliputi kegiatan pemuatan perhatian terhadap suatu objek dengan menggunakan seluruh alat indra (pengamatan langsung), tes evaluasi pada setiap siklus, dalam penelitian ini digunakan tes prestasi yang digunakan untuk mengukur pencapaian seseorang setelah mempelajari sesuatu. Sumber data penelitian ini berasal dari peneliti, guru sebagai observer, dan siswa kelas V SD negeri 1 Jero Gunung Kecamatan Sakra Barat Kabupaten Lombok Timur Tahun Pelajaran 2021/2022.

Jenis data yang didapatkan adalah kualitatif dan kuantitatif yang terdiri dari data hasil belajar (data kuantitatif) dan data hasil observasi pelaksanaan pembelajaran (data kualititatif). 


\section{HASIL DAN PEMBAHASAN}

Data kondisi awal pra siklus persentase hasil belajar lari sprint siswa kelas V SD Negeri 1 Jero Gunung Kecamatan Sakra barat kabupaten Lombok Timur sangat rendah menunjukan $30 \%$ atau siswa yang mencapai ketuntasan belajar hanya sejumlah 12 siswa. Sedangkan nilai rata-rata hasil belajar lari sprint sebesar $71 \%$.

\section{Hasil}

\section{Siklus 1}

\section{a. Perencanaan}

Pada tahap perencanaan dilakukan dengan menyusun perencanaan tindakan berdasarkan identifikasi masalah pada obeservasi awal sebelum penelitian dilaksanakan. Rencana tindakan ini mencakup semua langkah tindakan secara rinci pada tahap ini segala keperluan pelaksanaan peneliti tindakan kelas dipersiapkan mulai dari bahan ajar, rencana pembelajaran, metode dan strategi pembelajaran, pendekatan yang akan digunakan, subjek penelitian serta teknik dan instrumen observasi disesuaikan dengan rencana.

\section{b. Pelaksanaan Tindakan}

Dalam tahap pelaksanaan tindakan dilaksanakan kegiatan pembelajaran sesuai dengan rencana pelaksanaan pembelajaran yang telah dibuat. Untuk dapat menyesuaikan rencana pelaksanaan pembelajaran dalam penyampaian materi, termasuk didalamnya pembelajaran menggunakan metode kualitatif dengan teknik penelitian tindakan kelas (classroom Action Research), dilaksanakan dalam 3 kali pertemuan, dimana 2 kali pertemuan untuk penyampaian materi dan 1 kali pertemuan untuk evaluasi.

\section{c. Observasi dan Evaluasi}

\section{Observasi}

Hasil observasi diperoleh dari hasil pengamatan yang dilakukan oleh observer yang dilakukan oleh rekan guru peneliti dengan mengisi lembar observasi aktivitas guru dan aktivitas siswa untuk merekam jalannya proses pembelajaran. Dari hasil observasi dan pengamatan yang dilakukan, didapatkan bahwa proses pembelajaran belum sesuai dengan yang diharapkan karena masih terdapat kekurangan-kekurangan baik dari pihak guru sendiri maupun dari pihak siswa.

Berdasarkan hasil observasi terhadap aktivitas siswa setelah dianalisa diperoleh data sebagai berikut :

Tabel 1. Hasil Observasi Aktivitas Siswa Pada Siklus I

\begin{tabular}{llllllllll}
\hline \multirow{2}{*}{ Pertemuan } & \multicolumn{4}{c}{ Jumlah skor yang tampak } & \multicolumn{2}{c}{$\sum$ Skor } & Rata-rata & Kategor \\
Pertama & 1 & 2 & 3 & 4 & 5 & 6 & aktivitas & Aktivitas & i \\
& 4,0 & 2,7 & 3,0 & 2,7 & 3,3 & 2,7 & 18,3 & 3,1 & Cukup \\
Kedua & 4,3 & 3,0 & 3,3 & 3,0 & 3,7 & 3,7 & 21,0 & 3,5 & Aktif \\
\hline
\end{tabular}

Dari tabel di atas dapat dilihat bahwa aktivitas belajar siswa pada siklus I pertemuan 1 adalah 3,1 \% dengan kategori cukup Aktif dan pertemuan 2 adalah 3,5\% kategori sangat aktif. Oleh karena itu maka aktivitas siswa pada siklus berikutnya masih perlu ditingkatkan.

\section{Evaluasi Hasil Belajar}

Pelaksanaan tindakan dalam siklus I yang dilakukan peneliti dan dibantu kolaborator adalah mengambil data penelitian berupa nilai ketuntasan hasil belajar. Data hasil ketuntasan belajar siswa pada materi lari sprint melalui penerapan permainan hijau hitam dianalisis melalui pencapaian indikator yang telah ditentukan. Adapun deskripsi data peningkatan kemampuan lari sprint pada siklus I ketuntasan belajar mencapai $71 \%$. 
Data tersebut menunjukan adanya kemajuan hasil belajar materi sprint pada siswa kelas V SD Negeri 1 Jero Gunung Kecamatan Sakra Barat Kabupaten Lombok Timur Tahun Pelajaran 2021/2022. Kemajuan hasil belajar ini karena adanya 12 siswa yang memperoleh nilai diatas KKM dari kondisi awal pra siklus ke siklus I. Sehingga jumlah keseluruhan ketuntasan belajar pada siklus I sejumlah 12 siswa. Kualitas gerak serta jawaban siswa cukup memadai karena dari 17 siswa yang bisa menjawab dengan benar sejumlah 12 sedangkan 5 siswa lainnya jawabannya masih kurang. Kemampuan menjawab soal dapat dikatakan bagus karena jawaban tersebut dikomentari dengan kata-kata logis, singkat, kalimat bagus dan benar. Sedangkan nilai rata-rata hasil

\section{d. Refleksi} belajar meningkat sejumlah $71 \%$

Berdasarkan analisis hasil observasi pada siklus I, jumlah siswa yang tuntas masih $71 \%$ berarti masih dibawah standar minimum yakni $85 \%$. Hasil tersebut belum mencapai hasil yang diharapkan, untuk itu peneliti melanjutkan ke siklus berikutnya. Dalam siklus I ini terdapat kekurangan-kekurangan yang perlu untuk dipehatikan dan diperbaiki pada kegiatan siklus II.

\section{Hasil Penelitian Siklus II}

Proses pembelajaran pada siklus II diawali dengan pemberian umpan balik dari hasil evaluasi yang diberikan. Oleh karena itu, sebelum berdiskusi guru menghimbau agar siswa tidak ada yang ngobrol, mengganggu temannya yang lain, dan tidak ada siswa yang diam memperhatikan teman-temannya, demikian juga pembagian tugas dalam setiap kelompok harus lebih jelas sehingga siswa dapat melaksanakan tugasnya masing-masing.

\section{a. Perencanaan}

Pelaksanaan siklus II peneliti melakukan penelitian kembali dengan berpedoman dari hasil siklus I serta mengambil data yang diperlukan sebagai bahan evaluasi.

\section{b. Pelaksanaan Tindakan}

Dalam tahap pelaksanaan tindakan dilaksanakan kegiatan pembelajaran sesuai dengan rencana pelaksanaan pembelajaran yang telah dibuat. Untuk dapat menyesuaikan rencana pelaksanaan pembelajaran dalam penyampaian materi, termasuk didalamnya pembelajaran dengan menggunakan metode kualitatif dengan Teknik penelitian Tindakan kelas (Clasroom Action Research) dilaksanakan dalam 3 kali pertemuan, dimana 2 kali pertemuan untuk penyampaian materi dan 1 kali pertemuan untuk evaluasi.

\section{c. Observasi dan Evaluasi}

\section{Hasil Observasi}

Hasil observasi diperoleh dari hasil pengamatan yang dilakukan oleh observer yang dilakukan oleh rekan guru peneliti dengan mengisi lembar observasi aktivitas guru dan aktivitas siswa untuk merekam jalannya proses pembelajaran. Hal ini dapat dilihat pada tabel skor aktivitas siswa mengalami peningkatan dari pertemuan pertama ke pertemuan ke dua, seperti yang terlihat pada tabel dibawah ini.

Tabel 2. Hasil Observasi Aktivitas Siswa Pada Siklus II

\begin{tabular}{|c|c|c|c|c|c|c|c|c|c|}
\hline \multirow[b]{2}{*}{ Pertemuan } & \multicolumn{6}{|c|}{ Jumlah skor yang tampak } & \multirow{2}{*}{$\begin{array}{c}\sum \text { Skor } \\
\text { aktivita } \\
\text { s }\end{array}$} & \multirow[b]{2}{*}{$\begin{array}{l}\text { Rata-rata } \\
\text { Aktivitas }\end{array}$} & \multirow{2}{*}{$\begin{array}{c}\text { Kategor } \\
\text { i }\end{array}$} \\
\hline & 1 & 2 & 3 & 4 & 5 & 6 & & & \\
\hline Pertama & 3 & 2,7 & 3 & 2,7 & 3,3 & 2,7 & 17,3 & 2,9 & $\begin{array}{l}\text { Cukup } \\
\text { Aktif }\end{array}$ \\
\hline Kedua & 3,7 & 3,3 & 3,7 & 3,3 & 3,7 & 3,7 & 21,3 & 3,6 & Aktif \\
\hline
\end{tabular}

Dari tabel diatas dilihat bahwa aktivitas siswa pada siklus II untuk pertemuan 1 adalah 2,9 dengan kategori cukup aktif dan pertemuan 2 adalah 3,6 dengan kategori aktif 2. Evaluasi Hasil Belajar 
Hasil evaluasi yang diperoleh pada siklus II ini mencapai tingkat 88,24\% jadi sudah dapat dikatakan tuntas, untuk itu tidak perlu lagi diadakan pembelajaran pada siklus berikutnya dengan ketuntasan belajar yang sudah dicapai, dengan demikian pembelajaran dengan menerapkan metode kualitatif dengan Teknik penelitian Tindakan kelas (Classroom Action Research) dikatakan dapat meningkatkan hasil / prestasi belajar Mata Pelajaran PJOK materi lari Sprint.

\section{d. Refleksi}

Dari hasil observasi aktivitas siswa pada siklus II, kegiatan pembelajaran sudah dapat berjalan dengan baik, dimana hasil observasi aktivitas siswa dengan hasil pertemuan 1 kategori cukup aktif dan pertemun 2 dengan kategori sangat aktif. Dari hasil analisis terhadap hasil evaluasinya terjadi peningkatan rata-rata kelas maupun persentase ketuntasan secara klasikal sudah mencapai/melebihi $88,24 \%$ artinya sudah $88,24 \%$ atau lebih siswa sudah mencapai nilai hasil ulangan sebesar KKM atau melebihi KKM yang ditentukan. Oleh karena itu penelitian ini dihentikan sampai siklus II sesuai dengan perencanaan.

\section{Pembahasan}

Strategi pembelajaran adalah suatu kegiatan pembelajaran yang harus dikerjakan oleh guru dan siswa agar tujuan pembelajaran dapat dicapai secara efektif dan efisien (Waluyo, 2011 :27).

Penelitian tindakan kelas ini dilaksanakan sebagai upaya untuk meningkatkan hasil belajar mata pelajaran PJOK materi lari sprint melalui permainan hitam-hijau pada siswa kelas V SD Negeri 1 Jero Gunung Kecamatan Sakra Barat Kabupaten Lombok Timur dengan melaksanakan pembelajaran dengan menerapkan/menggunakan metode kualitatif dengan teknik penelitian tindakan kelas (Classroom Action research) di SD Negeri 1 Jero Gunung Kecamatan Sakra Barat Kabupaten Lombok Timur Tahun Pembelajaran 2021/2022.

Hasil belajar menurut Nasution dalam Sunarto (2005) mendefinisikan prestasi belajar adalah kesempurnaan yang dicapai seseorang dalam berfikir, merasa dan berbuat. Prestasi belajar dikatakan sempurna apabila memenuhi tiga aspek yakni: kognitif (pengetahuan), afektif (sikap) dan psi komotor (keterampilan), sebaliknya dikatakan prestasi kurang memuaskan jika seseorang belum mampu memenuhi target dalam ketiga kriteria tersebut. Nana Sudjana (2009: 3) mendefinisikan hasil belajar siswa pada hakikatnya adalah perubahan tingkah laku sebagai hasil belajar dalam pengertian yang lebih luas mencakup bidang kognitif, afektif, dan psikomotorik.

Berdasarkan hasil analisis data pada tiap siklus, terlihat bahwa hasil dari siklus I ke siklus II mengalami peningkatan. Pada pelaksanaan pembelajaran dan hasil analisis data siklus I, untuk aktivitas siswa diperoleh kategori Cukup Aktif dan aktivitas siswa pada siklus II diperoleh aktivitas siswa dengan kategori aktif.

Terkait dengan hasil ulangan pada siklus I dan II dapat dilihat rinciannya dibawah ini :

\begin{tabular}{clc} 
Tabel 3 : Ringkasan Hasil Evaluasi Pada Siklus I \\
\hline No & \multicolumn{1}{c}{ Uraian } & Hasil \\
1 & Nilai Terendah & 50 \\
2 & Nilai Tertinggi & 80 \\
3 & Rata-rata & 72,94 \\
4 & $\begin{array}{l}\text { Jumlah siswa yang } \\
\text { tuntas }\end{array}$ & 12 \\
5 & $\begin{array}{l}\text { Jumlah siswa yang } \\
\text { ikut tes }\end{array}$ & 17 \\
6 & $\begin{array}{l}\text { Persentase yang } \\
\text { tuntas }\end{array}$ & $71 \%$ \\
\hline
\end{tabular}

Sedangkan pada siklus II hasilnya sebagai berikut : 


\begin{tabular}{cll} 
Tabel 4 : Ringkasan Hasil Evaluasi Pada Siklus II \\
\hline No & \multicolumn{1}{c}{ Uraian } & Hasil \\
1 & Nilai Terendah & 50 \\
2 & Nilai Tertinggi & 85 \\
3 & Rata-rata & 78,82 \\
4 & Jumlah siswa & 15 \\
& $\begin{array}{l}\text { yang tuntas } \\
5\end{array}$ & $\begin{array}{l}\text { Jumlah siswa } \\
\text { yang ikut tes }\end{array}$ \\
6 & $\begin{array}{l}\text { Persentase } \\
\text { yang tuntas }\end{array}$ & $88,24 \%$ \\
\hline
\end{tabular}

Setelah melihat kedua tabel hasil evaluasi dari siklus I dan II dimana nilai yang mereka peroleh sudah mencapai tingkat ketuntasan belajar. Dan melebihi tingkat ketuntasan belajar secara klasikal yaitu $88,24 \%$.

Penelitian tindakan kelas ini dilaksanaan sebagai upaya untuk meningkatkan aktivitas dan prestasi atau hasil belajar mata pelajaran PJOK pada materi lari sprint melalui penerapan permainan hitam-hijau pada siswa kelas V SD Negeri 1 Jero Gunung Kecamatan Sakra Barat Tahun Pelajaran 2021/2022. Dimana penelitian ini dilakukan dalam dua siklus.

Pembahasan dimaksudkan untuk memaknai hasil penelitian sesuai dengan teori yang digunakan dan tidak sekadar menjelaskan temuan. Pembahasan harus diperkaya dengan merujuk hasil-hasil penelitian sebelumnya yang telah terbit dalam jurnal ilmiah.

Penulisan rujukan dalam badan artikel menggunakan pola berkurung (). Jika hanya ada satu penulis: contoh (Retnowati, 2018); jika ada dua penulis: contoh (Nurgiyantoro \& Efendi, 2017). Jika dua sampai lima penulis, untuk penyebutan yang pertama ditulis semua: contoh (Retnowati, Fathoni, \& Chen, 2018) dan penyebutan berikutnya ditulis (Retnowati et al., 2018). Penulis lebih dari tiga orang hanya ditulis pengarang pertama diikuti et al., contoh (Janssen et al.' 2010); Penulisan rujukan juga dapat ditulis dengan nama di luar tanda kurung, misalnya Nurgiyantoro (2017) sesuai dengan stile penulisan. Jika pernyataan yang dirujuk merupakan kutipan langsung atau fakta tertentu, halaman harus disertakan: contoh (Nurgiyantoro \& Efendi, 2017:144) atau jika mengambil substansi dari beberapa halaman: contoh (Nurgiyantoro \& Efendi, 2017:144-146).

Perujukan lebih disarankan bukan berupa kutipan langsung atau tidak memuat terlalu banyak kutipan langsung. Namun, jika ada kutipan langsung yang jumlahnya kurang dari 40 kata, ia harus ditulis dalam paragraf (tidak dipisah) dan dengan diberi tanda kutip (“...”). Jika kutipan langsung berisi 40 kata atau lebih, ia ditulis dalam blok (terpisah dari paragraf), menjorok setengah inchi dari pinggir, tanpa diberi tanda kutip dan diikuti nama, tahun, halaman dalam tanda kurung (nama, tahun:halaman).

Jika suatu pernyataan saripati dari beberapa referensi, semua sumber ditulis dengan menyebutkan semua referensi urut alfabet dan tanda titik koma (;) untuk memisahkan antarsumber, contoh (Sahlberg, 2012; Schunk, 2012; Retnowati, Fathoni, \& Chen, 2018). Untuk sumber rujukan terjemahan, yang dirujuk adalah nama pengarang asli, tahun buku terjemahan dan buku asli: contoh lihat di daftar pustaka buku dari (Schunk, 2012a) asli dan Schunk (2012b) terjemahan.

\section{KESIMPULAN}

Data penelitian menunjukan bahwa pelaksanaan pembelajaran lari sprint melalui penerapan permainan hitam hijau dapat menciptakan pembelajaran lebih aktif, siswa antusias mengikuti pembelajaran dan senang dalam melakukan tugas gerak yang diberikan guru sehingga keterampilan gerak siswa dan penguasaan materi lari sprint meningkat sehingga nilai hasil belajar lari sprint yang diperoleh siswa juga meningkat setelah melihat kedua tabel hasil evaluasi dari siklus I dan II dimana nilai yang mereka peroleh sudah mencapai tingkat 
ketuntasan belajar. Dan melebihi tingkat ketuntasan belajar secara klasikal yaitu 88, $24 \%$. Melalui penerapan permainan hitam hijau pada mata pelajaran PJOK materi pembelajaran lari sprint dapat meningkatkan hasil belajar siswa pada siswa kelas V SD Negeri 1 Jero Gunung Kecamatan Sakra Barat Kabupaten Lombok Timur Tahun Pelajaran 2021/2022.

\section{DAFTAR PUSTAKA}

Abdul Kadir Ateng,(1992), Azas dan Landasan Pendidikan Jasmani. Jakarta Depdikbud Dirjen Dikti

Abin Syamsudin M, 2002. Pendekatan Dan Metode Pembelajaran. Tersedia pada http://4.bp.blogspot.com. Diakses pada tgl .21 Oktober 2021

Agus Mahendra, 2008. Permainan Anak dan Aktivitas Ritmik. Jakarta: Universitas Terbuka

Anni, C.T,(2004). Psikologi Belajar, Semarang. UNNES Press

Arikunto, 2008. Penelitian Tindakan Kelas. Tersedia padahttp:// google.search.penelitiantindakankelas..comdiakses pada 21 Oktober 2021

Basrowi, 2008. Penelitian Tindakan Kelas. Tersedia pada http:// google.search.pengertianpenelitiantindakankelas..comDiakses pada 21 Oktober 2021

Dadan Heryana, 2010. Lari Sprint Atletik. Tersedia pada http://materipenjasorkes.blogspot.com/2012/08/teknik-star-jongkok-dan-larijarak.htmldiakses pada 21 Oktober 2021

Depdiknas. 2003. Undang - Undang RI Tahun 2003 tentang Sistem Pendidikan Nasional. Jakarta. Depdiknas.

M. Djumijar. 2004. Atletik tersedia pada http://www.google.com/search?q=pengertian+lari+sprint\&client=firefox diakses pada 21 Oktober 2021

Moh. Surya, 1997. Ciri-ciri perubahan perilaku belajar dari beberapa ahli pendidikan. http:// wikipedia. com. diakses pada tgl 21 Oktober 2021

Nadisah, (1992).Pengembangan kurikulum pendidikan jasmani dan kesehatan.Jakarta Depdikbud Dirjen Dikti

Rumini, 2003. Model Pembelajaran Atletik, Sekolah Dasar dan Madrasah Ibtidaiyah. Depdiknas.

Soegijanto, soedjarwo, (1992). Permainan Kecil.Jakarta: Depdikbud Dirjen Dikti

Sudjana, (1990). Strategi Pembelajaran. Jakarta : Universitas Terbuka

Sukmadinata, 2005. Pengertian Hasil Belajar. Tersedia pada http://pengertianhasilbelajar.google.comdiakses pada 21 Oktober 2021.

Sunarto, 2005. Pengertian Hasil Belajar dan Pembelajaran. Tersedia pada http://sunarto.wordpress.com. diakses pada 21 Oktober 2021. 